\title{
Tanggung Jawab Pendeteksian Kecurangan sebagai Pencegahan Kegagalan Audit (Studi pada Kantor Akuntan Publik di Jakarta)
}

\author{
Annisa Adha Minaryanti \\ Fakultas Ekonomi Universitas Pasunadan \\ Jl. Tamansari No. 6-8, Bandung 40116 \\ E-Mail:annisa_minaryanti@yahoo.com \\ Mochammad Ridwan \\ Fakultas Ekonomi Universitas Pasunadan \\ J1. Tamansari No. 6 - 8, Bandung 40116 \\ E-Mail:mridwan@unpas.ac.id
}

\begin{abstract}
This study aims to determine how the impact of fraud detection responsibility to the prevention of audit failure are. The object of this study includes responsibility of fraud detection as an independent variable whose influence the dependent variable (dependent), called the audit failure prevention. Method used in this study is the Correlative relationship research method, alongside the clausal relation as the type of relation between variable studied in this study. These variables were analyzing using the descriptive statistics and regression to test the hypothesis. The data collected obtained through questionnaires and auditors as respondents at Accounting Firm in Jakarta. After obtaining data, results tended to show that responsibility for fraud detection have significant effect on the audit failure prevention.
\end{abstract}

Keywords: fraud detection responsibility, failure audit prevention.

\begin{abstract}
ABSTRAK
Penelitian ini bertujuan untuk mengetahui seberapa besar pengaruh independensi, kompetensi dan tanggung jawab pendeteksian kecurangan terhadap pencegahan kegagalan audit. Objek penelitian meliputi independensi, kompetensi, dan tanggung jawab pendeteksian kecurangan sebagai variabel bebas atau independen yang dilihat pengaruhnya terhadap variabel tidak bebas atau dependen yaitu pencegahan kegagalan audit. Metode penelitian ini menggunakan metode penelitian deskriptif dengan tipe hubungan antara variabel yang diteliti adalah hubungan klausal. Variabel dianalisis dengan menggunakan statistik deskriptif dan regresi sederhana untuk menguji hipotesis. Data yang terkumpul diperoleh melalui penyebaran kuesioner, dengan responden auditor pada KAP yang ada di Jakarta. Hasil menunjukkan bahwa tanggung jawab pendeteksian kecurangan berpengaruh signifikan terhadap pencegahan kegagalan audit.
\end{abstract}

Kata Kunci: tanggung jawab pendeteksian kecurangan, pencegahan kegagalan audit. 


\section{PENDAHULUAN}

Profesi akuntan publik adalah profesi yang unik karena dalam menjalankan tugas profesinya seorang akuntan publik harus dapat menggunakan keahlian profesinya dengan tetap mempertahankan sikap independensi.

Seseorang yang dianggap profesional dalam melakukan pekerjaannya adalah seseorang yang salah satunya memiliki pengalaman dan pengetahuan, seperti yang dikemukakan oleh Bell et al. (2005) Professional judgment refers to judgments of persons with experience, extensive education, and/or specialized training within a profession.

Choo dan Trotman (1991) dalam penelitiannya memberikan bukti empiris bahwa auditor berpengalaman lebih banyak menentukan item-item yang tidak umum (atypical) dibandingkan auditor yang kurang berpengalaman, tetapi antara auditor yang berpengalaman dengan yang kurang berpengalaman tidak berbeda dalam menentukan item-item yang umum (typical).

Sedangkan menurut Libby dan Frederick (1990) dalam Tjun (2012) bahwa auditor yang berpengalaman mempunyai pemahaman yang lebih baik atas laporan keuangan sehingga keputusan yang diambil dapat lebih baik.

Berbeda dengan profesi lainnya yang harus menaati perintah atau keinginan pengguna jasa profesi karena fee yang diberikan, seorang akuntan publik justru harus independen dalam melaksanakan audit dan saat memberikan hasil laporan audit kepada klien, meskipun dibayar oleh klien karena hasil laporan audit ini tidak hanya digunakan oleh klien tetapi juga oleh pengguna laporan keuangan auditan.

Profesi auditor sedikit berbeda dengan profesi lain seperti pengacara atau dokter. Pengacara atau dokter, sebagai pihak pertama, bekerja untuk kepentingan klien sebagai pihak kedua yang merupakan pihak pemohon jasa. Namun auditor bukan saja dituntut untuk melayani klien (pihak kedua) tetapi auditor juga dituntut untuk melayani masyarakat (pihak ketiga) (Setiawan dan Ghozali, 2006).

Auditor bertugas untuk mengaudit atau memeriksa laporan keuangan suatu perusahaan, menurut Filipović dan Filipović (2008) pengertian auditing secara umum adalah sebagai berikut: auditing is seen as a 'link which builds trust' between the management board, which prepares and draws up financial statements, and users of information contained in these statements.

Pernyataan tersebut jika diterjemahkan adalah audit dipandang sebagai "link yang membangun kepercayaan" antara dewan manajemen, yang mempersiapkan dan menyusun laporan keuangan dan pengguna dari informasi yang terkandung dalam laporan keuangan.

Tanggung jawab utama auditor bukan pada klien sebagai pemohon jasa (pihak kedua) akan tetapi pada pihak ketiga atau pihak yang berkepentingan terhadap laporan keuangan tersebut seperti pemegang saham, calon investor, pemerintah, dan pihak yang berkepentingan lain. Hal ini merupakan karakteristik unik profesi auditor. Adanya tugas tersebut tidak serta merta menempatkan auditor pada posisi aman.

Menurut Agoes (2009), rasa tanggung jawab yang tinggi hanya dapat diwujudkan melalui pengembangan dan pemeliharaan kompetensi pada tinggkat yang tinggi. Dari pendapat tersebut dapat disimpulkan bahwa, rasa tanggung jawab yang besar dapat dibentuk dari kompetensi yang dimiliki oleh auditor tersebut, jika kompetensi yang dimiliki besar maka rasa tanggung jawab auditor pun juga besar.

Jika seorang auditor tidak memiliki sikap independen, kompetensi, dan tanggung jawab dalam memeriksa laporan keuangan suatu perusahaan maka akan mengakibatkan terjadinya kecurangan. Yang mana kecurangan tersebut dapat dikatakan sebagai kegagalan audit (audit failure).

Menurut menurut Salehi dan Azary (2008), mengemukakan bahwa kecurangan meliputi penyalahgunaan sumber daya maupun pelaporan yang tidak benar tentang penggunaan sumber daya oleh manajemen, sehingga untuk mencegah kegagalan audit diperlukan kemampuan auditor untuk mendeteksi kecurangan manajemen tersebut.

Terdapat beberapa pendapat mengenai penyebab terjadinya kegagalan audit. Terkait kegagalan audit (audite failure) yang disebabkan oleh hubungan kedekatan (relationship) antara auditor dengan klien seperti yang diuraikan oleh Bazerman et al. (1997) yaitu bahwa kegagalan audit adalah sebagai hasil dari adanya kolusi antara auditor dengan klien dalam penerbitan laporan keuangan yang salah (faulty financial statement). 
Kegagalan audit terjadi karena suatu audit dilaksanakan dengan tidak atau tanpa menerapkan standar audit yang dapat diterima umum sehingga mengeluarkan pendapat yang salah (Arens et al., 2012). Dengan kata lain seorang auditor telah melakukan kegagalan audit (audit failure), apabila auditor tersebut tidak berhasil menemukan temuan yang seharusnya ditemukan atau tidak bisa menemukan kesalahan yang material.

Ballou et al. (2001) mengemukakan bahwa audit yang berorientasi pada pengetahuan tentang bisnis klien dapat mencegah kegagalan audit, di mana auditor akan mengalokasikan dengan lebih baik pengujian pada area yang memiliki risiko audit sehingga kesalahan yang material dapat dideteksi dan ditemukan.

Sikap tanggung jawab seorang auditor dalam memeriksa laporan keuangan yaitu dengan memberikan opini atas kewajaran pelaporan keuangan organisasi, terutama dalam penyajian posisi keuangan dan hasil operasi dalam suatu periode. Mereka juga menilai apakah laporan keuangan organisasi disajikan sesuai dengan prinsip-prinsip akuntansi yang diterima secara umum, diterapkan secara konsisten dari periode ke periode, dan seterusnya. Jika auditor menemukan bahwa laporan keuangan tidak disajikan sesuai dengan prinsip-prinsip akuntansi yang diterima secara umum atau menemukan adanya kecurangan dalam laporan keuangan maka auditor bertanggung jawab untuk melaporkan temuan tersebut. Jika auditor tidak melaporkan temuan tersebut maka auditor tersebut tidak memiliki sikap tanggung jawab dan hal tersebut akan mengakibatkan kegagalan audit.

Kegagalan audit juga dapat diakibatkan oleh kurang relevannya informasi yang menyebabkan lemahnya tanggung jawab pendeteksian kecurangan oleh seorang auditor. Kondisi tersebut menunjukkan adanya efek dilusi dalam pertimbangan auditor. Adanya informasi yang tidak relevan (disebut juga bukti non diagnostik) yang bercampur dengan informasi relevan (bukti diagnostik atau red flag dalam pendeteksian kecurangan) akan mengakibatkan penilaian risiko kecurangan oleh auditor menjadi kurang ekstrim. Penilaian risiko yang tidak sensitif ini akan berakibat lemahnya tanggung jawab pendeteksian kecurangan seorang auditor (Hackenbrack, 1992).

Beberapa kasus skandal akuntansi dalam tahuntahun belakangan ini memberikan bukti lebih jauh tentang kegagalan audit yang disebabkan oleh kurangnya sikap independensi, kompetensi, dan tanggung jawab auditor dalam mendeteksi kegagalan audit, yang membawa akibat serius bagi masyarakat bisnis. Kasus seperti itu terjadi pada Enron, Global Crossing, dan WorldCom di Amerika Serikat yang mengakibatkan kegemparan besar dalam pasar modal. Kasus serupa terjadi di Indonesia seperti PT Kimia Farma. Meski beberapa salah saji yang terjadi belum tentu terkait dengan kecurangan, tetapi Faktor risiko yang berkaitan dengan kecurangan oleh manajemen terbukti ada pada kasus tersebut. Sebagai contoh di Indonesia dapat dikemukakan kasus yang terjadi pada PT Kimia Farma Tbk (PT KF). PT Kimia Farma adalah salah satu produsen obat-obatan milik pemerintah di Indonesia.

Pada audit tanggal 31 Desember 2001, manajemen Kimia Farma melaporkan adanya laba bersih sebesar 132 miliar rupiah, dan laporan tersebut di audit oleh Hans Tuanakotta \& Mustofa (HTM). Akan tetapi, Kementerian BUMN dan Bapepam menilai bahwa laba bersih tersebut terlalu besar dan mengandung unsur rekayasa. Setelah dilakukan audit ulang, pada 3 Oktober 2002 laporan keuangan Kimia Farma 2001 disajikan kembali (restated), karena telah ditemukan kesalahan yang cukup mendasar. Pada laporan keuangan yang baru, keuntungan yang disajikan hanya sebesar 99,56 miliar rupiah, atau lebih rendah sebesar 32,6 miliar rupiah, atau 24,7\% dari laba awal yang dilaporkan. Kesalahan itu timbul pada unit Industri Bahan Baku yaitu kesalahan berupa overstated penjualan sebesar 2,7 miliar rupiah, pada unit Logistik Sentral berupa overstated persediaan barang sebesar 23,9 miliar rupiah, pada unit Pedagang Besar Farmasi berupa overstated persediaan sebesar 8,1 miliar rupiah dan overstated penjualan sebesar 10,7 miliar rupiah.

Dalam konteks skandal keuangan tersebut, memunculkan pertanyaan apakah trik-trik rekayasa tersebut tidak mampu terdeteksi oleh akuntan publik yang mengaudit laporan keuangan tersebut, atau sebenarnya telah terdeteksi namun auditor justru ikut mengamankan praktik kejahatan tersebut.

Tentu saja jika yang terjadi adalah auditor tidak mampu mendeteksi trik rekayasa laporan keuangan maka yang menjadi inti permasalahannya adalah lemahnya kompetensi atau keahlian auditor tersebut. Namun jika yang terjadi bahwa seorang akuntan publik ikut mengamankan praktik rekayasa tersebut, seperti yang terungkap juga pada skandal yang menimpa 
Xerox, WorldCom, Tyco, Global Crossing, Adelphia, dan Walt Disney (Sunarsip, 2002 dalam Christiawan, 2005) maka inti permasalahannya adalah independensi auditor tersebut atau kurangnya tanggung jawab auditor terhadap pendeteksian kecurangan.

Penelitian sebelumnya yang dilakukan oleh Prasetyo (2010) yang berjudul "Pengaruh Independensi, Kompetensi, dan Tanggung Jawab Pendeteksian Kecurangan terhadap Pencegahan kegagalan Audit" penelitiannya dilakukan pada AKN III BPK RI Jakarta yang mana pemeriksaan dilakukan berdasarkan Standar Pemeriksaan Keuangan Negara (SPKN) dan Standar Akuntansi Pemerintah yang tertuang dalam PP No. 71 tahun 2010 dengan subjek pemeriksaan adalah sektor pemerintahan, dengan hasil penelitian bahwa Tanggung Jawab Pendeteksian Kecurangan berpengaruh signifikan terhadap Pencegahan Kegagalan Audit. Sedangkan penelitian yang akan penulis lakukan yaitu pada kantor akuntan publik di Jakarta yang menggunakan Standar Profesional Akuntan Publik (SPAP) dan Pernyataan Standar Akuntansi Keuangan (PSAK) dengan subjek sektor privat dan berorientasi pada laba.

Maksud dari penelitian ini adalah untuk memperoleh bukti empiris dan menemukan kejelasan fenomena tentang tanggung jawab pendeteksian kecurangan sebagai pencegahan kegagalan audit pada pada kantor akuntan publik di Jakarta. Adapun tujuan penelitian ini adalah untuk mengkaji pengaruh tanggung jawab pendeteksian kecurangan auditor terhadap pencegahan kegagalan audit.

Tanggung jawab auditor menurut SA seksi 110 (PSA No. 02) adalah auditor bertanggung jawab untuk merencanakan dan melaksanakan audit untuk memperoleh keyakinan memadai tentang apakah laporan keuangan bebas dari salah saji material, baik yang disebabkan oleh kekeliruan atau kecurangan. Oleh karena sifat bukti audit dan karakteristik kecurangan, auditor dapat memperoleh keyakinan memadai, namun bukan mutlak, bahwa salah saji material terdeteksi. Auditor tidak bertanggung jawab untuk merencanakan dan melaksanakan audit guna memperoleh keyakinan bahwa salah saji terdeteksi, baik yang disebabkan oleh kekeliruan atau kecurangan, yang tidak material terhadap laporan keuangan.

Baik kecurangan yang di sengaja maupun yang tidak di sengaja berakibat serius dan membawa banyak kerugian, oleh karena itu auditor harus dapat mendeteksi kecurangan tersebut. Menurut Statement on Auditing Standard (SAS) No. 99 mengenai
Consideration of Fraud in a Financial Statement Audit menyatakan bahwa auditor mempunyai tanggung jawab yang besar untuk mendeteksi kecurangan dengan merencanakan dan melaksanakan audit untuk memperoleh kepastian mengenai apakah laporan keuangan bebas dari salah saji (misstatement) secara material baik yang disebabkan oleh kesalahan atau kecurangan (ACIPA, 2002).

Tanggung jawab akuntan publik untuk melindungi kepentingan publik semakin bertambah seiring dengan bertambahnya investor di pasar modal, sejalan dengan hubungan yang semakin erat antara para manajer korporat dan pemegang saham, serta sejalan dengan pemerintah dalam meningkatkan ketergantungannya pada informasi akuntansi (Herusetya, 2007).

Tanggung jawab pendeteksian kecurangan (fraud detection) akan mendukung terwujudnya penerapan standar yang memadai untuk menunjang tanggung jawab pendeteksian kecurangan, membantu terwujudnya lingkungan kerja audit, metode dan prosedur audit yang cukup efektif untuk tanggung jawab pendeteksian kecurangan sehingga tidak terjadi kegagalan audit (Tackett et al., 2006; Koroy, 2008).

Rasa tanggung jawab yang tinggi hanya dapat diwujudkan melalui pengembangan dan pemeliharaan kompetensi pada tingkat yang tinggi (Agoes, 2009). Seorang auditor bertanggung jawab untuk mendeteksi kecurangan dalam laporan keuangan agar tidak terjadi kegagalan audit, untuk dapat mendeteksi kecurangan dalam laporan keuangan seorang auditor membutuhkan kompetensi melalui pengalaman dan pengetahuan dalam mendeteksi kecurangan. Jika seorang auditor tidak memiliki kompetensi melalui pengalaman dan pengetahuan maka seorang auditor tidak mungkin dapat bertanggung jawab dalam mendeteksi kecurangan.

Auditor tidak hanya diharuskan untuk menjaga sikap mental independen dalam menjalankan tanggung jawabnya, namun juga penting bagi para pengguna laporan keuangan untuk memiliki kepercayaan terhadap independensi auditor (Arens et al., 2012).

Berdasarkan penjelasan tersebut mengindikasikan bahwa semakin tinggi tanggung jawab pendeteksian kecurangan, maka tingkat pencegahan kegagalan audit semakin baik, hal ini dipertegas juga oleh penelitian Prasetyo (2010) yang menggunakan subjek yang berbeda yaitu Kantor Akuntan Publik di Jakarta, menunjukkan bahwa terdapat pengaruh antara tanggung jawab pendeteksian kecurangan terhadap pencegahan kegagalan audit. 


\section{METODE}

Menurut Sekaran (2011) variabel independen adalah variabel yang mempengaruhi variabel terikat entah secara positif maupun negatif, sedangkan variabel dependen yang dapat juga dikatakan sebagai variabel terikat dan merupakan variabel utama yang menjadi faktor yang berlaku dalam investigasi. Maka variabel independen dari penelitian ini adalah tanggung jawab pendeteksian kecurangan, sedangkan variabel dependen dari penelitian ini adalah pencegahan kegagalan audit. Penelitian ini bertujuan untuk mengukur sejauh mana pengaruh tanggung jawab pendeteksian kecurangan terhadap pencegahan kegagalan audit. Untuk meneliti objek tersebut diadakan penelitian terhadap rekan auditor (auditor partner) untuk dijadikan sampel penelitian.

Adapun yang menjadi subjek penelitiannya adalah seluruh auditor partner di Kantor Akuntan Publik (KAP) yang berada di wilayah Jakarta. Pertanyaan yang dibuat dalam kuesioner berjumlah 42 pertanyaan yang ditunjukkan kepada auditor partner yang bekerja pada kantor akuntan publik (KAP) di Jakarta dan terdaftar di Ikatan Akuntan Indonesia (IAI) pada tahun 2012. Daftar seluruh KAP yang berada di wilayah Jakarta berjumlah 273 kantor akuntan publik.

Populasi dalam penelitian ini adalah semua auditor Partner yang bekerja di KantorAkuntan Publik (KAP) di Jakarta yang berjumlah 237 Kantor Akuntan Publik yang terdaftar di IAI pada tahun 2012. Untuk keperluan penelitian ini maka akan diambil sampel sebanyak 50 auditor partner yang bekerja pada KAP (Kantor Akuntan Publik) di Jakarta. Dikarenakan populasi dianggap homogen maka pemilihan sampel dilakukan dengan teknik simple random sampling yaitu pengambilan anggota sampel dari populasi dilakukan secara acak tanpa memperlihatkan strata yang ada dalam populasi.

Teknik pengumpulan data dalam penelitian ini menggunakan kuesioner jenis tertutup dengan skala likert dan memiliki dua tipe pertanyaan yaitu pertanyaan positif dan pertanyaan negatif. Untuk variabel tanggung jawab pendeteksian kecurangan diukur melalui lima indikator dengan delapan butir pertanyaan. Berikutnyavariabelpencegahankegagalan audit diukur melalui empat indikator dengan sepuluh butir pertanyaan. Adapun operasionalisasi variabel dalam penelitian ini dapat dilihat pada Tabel 1 .
Analisis data yang digunakan dalam penelitian ini adalah analisis deskriptif dan asosiatif. Untuk menguji instrumen penelitian dilakukan uji validitas dengan menggunakan pearson product-moment dan uji reliabilitas dengan menggunakan cronbach's alpha. Pengujian hipotesis menggunakan regresi sederhana yang sebelumnya dilakukan transformasi data dengan method successive of interval untuk memenuhi persyaratan penggunaan alat analisis multivariate (regresi sederhana).

\section{HASIL}

Pengiriman kuesioner dilakukan pada tanggal 1 April 2013 dan pengambilan kuesioner dilakukan pada tanggal 1 Mei 2013 sampai dengan 4 Mei 2013. Jumlah kuesioner yang dikirim sebanyak 50 eksemplar berhasil kembali dan diisi dengan responden partner di KAP. Sebanyak 41 kuesioner yang terisi dengan respons rate sebesar $82 \%$.

Hasil pengujian validitas menunjukkan bahwa setiap item pertanyaan dalam penelitian ini memiliki nilai lebih besar dari 0.3 sehingga dapat dikatakan valid. Untuk uji reliabilitas menunjukkan masingmasing nilai untuk setiap variabel penelitan sebesar 0.894 dan 0.896 , nilai tersebut lebih besar dari 0.70 sehingga dapat dikatakan reliabel. Hasil tanggapan responden terhadap variabel penelitian ini dapat dilihat pada Tabel 2.

Berdasarkan pada hasil analisis deskriptif mengenai tanggung jawab pendeteksian kecurangan memiliki total skor rata-rata sebesar 4,21 dan berada pada interval $4-5$. Dengan demikian dapat disimpulkan bahwa tanggung jawab auditor pada sebagian besar Kantor Akuntan Publik yang ada di wilayah DKI Jakarta dalam pendeteksian kecurangan termasuk tinggi. Bila dilihat berdasarkan indikator, terlihat bahwa rata-rata skor penilaian responden terhadap indikator penggunaan alat bantu dan professional judgment masih termasuk dalam kategori cukup.

Berikutnya tanggapan responden mengenai pencegahan terjadinya kegagalan audit memiliki total skor sebesar 3,98 dan berada pada interval 3 - 4. Dengan demikian dapat disimpulkan bahwa pencegahan terjadinya kegagalan audit yang dilakukan auditor pada sebagian besar kantor akuntan publik yang ada di wilayah DKI Jakarta termasuk cukup baik. 
Tabel 1. Operasionalisasi Variabel Penelitian

\begin{tabular}{|c|c|c|c|}
\hline Variabel & Konsep Variabel & Indikator & Skala \\
\hline $\begin{array}{l}\text { Tanggung jawab } \\
\text { pendeteksian } \\
\text { kecurangan } \\
\text { (responsibility for } \\
\text { fraund detection) (X) } \\
\text { Koroy (2008) }\end{array}$ & $\begin{array}{l}\text { Tanggung jawab untuk Pendeteksian } \\
\text { Kecurangan adalah tanggung jawab auditor } \\
\text { untuk mendeteksi suatu perbuatan yang } \\
\text { bertentangan dengan kebenaran dan } \\
\text { dilakukan dengan sengaja yang dapat berupa } \\
\text { manfaat dokumen yang salah, penyembunyian } \\
\text { informasi yang seharusnya diungkapkan, dan } \\
\text { pengelolaan dana yang tidak benar sebagai } \\
\text { suatu tundakan kriminal, untuk memperoleh } \\
\text { sesuatu yang bukan hak pelakunya. }\end{array}$ & $\begin{array}{l}\text { a. Menerapkan metode audit } \\
\text { b. Penggunaan alat bantu (decision } \\
\text { aids) } \\
\text { c. Professional Judgment } \\
\text { d. Skeptisisme profesional } \\
\text { e. Penilaian risiko terjadinya } \\
\text { kecurangan dalam perencanaan } \\
\text { audit }\end{array}$ & Ordinal \\
\hline $\begin{array}{l}\text { Pencegahan } \\
\text { terjadinya kegagalan } \\
\text { audit (audit failure } \\
\text { preventive) }(\mathrm{Y})\end{array}$ & $\begin{array}{l}\text { Pencegahan terjadinya kegagalan audit } \\
\text { (audit failure preventive) adalah pencegahan } \\
\text { terjadinya kegagalan auditor, yang mana } \\
\text { auditor tidak melaporkan semua kesalahan } \\
\text { yang material, memberikan pendapat atau } \\
\text { opini atas laporan keuangan yang tidak } \\
\text { mencerminkan kondisi keuangan audit yang } \\
\text { sebenarnya, tidak melakukan pendeteksian } \\
\text { dan penemuan kesalahan yang material, } \\
\text { tidak menerapkan tidak menerapkan } \\
\text { standar pemeriksaan yang berlaku, dan tidak } \\
\text { melakukan tanggung jawab pendeteksian } \\
\text { kecurangan. }\end{array}$ & $\begin{array}{l}\text { a. Auditor melaporkan temuan } \\
\text { pemeriksaan yang material } \\
\text { b. Auditor memberikan opini } \\
\text { atas laporan keuangan yang } \\
\text { sesuai kondisi keuangan yang } \\
\text { sebenarnya. } \\
\text { c. Melakukan pendeteksian } \\
\text { kesalahan material } \\
\text { d. Kemampuan auditor dalam } \\
\text { mengenali kecurangan yang } \\
\text { material. }\end{array}$ & Ordinal \\
\hline
\end{tabular}

Tabel 2 Rekapitulasi Tanggapan Responden

\begin{tabular}{lrrr}
\hline \multicolumn{1}{c}{ No } & \multicolumn{1}{c}{ Indikator } & Skor Rata-Rata & Kriteria \\
\hline \multicolumn{2}{l}{$\begin{array}{l}\text { Pencegahan Terjadinya Kegagalan Audit (Y) } \\
1\end{array} \quad$ Melaporkan temuan pemeriksaan yang material } & 3.99 & Sering \\
2 & Memberikan opini atas laporan keuangan yang sesuai kondisi keuangan yang sebenarnya & 4.63 & Selalu \\
3 & Melakukan pendeteksian kesalahan material & 3.25 & Sering \\
4 & Kamampuan dalam mengenali kecurangan yang material & 4.06 & Baik \\
Total Skor Rata-Rata & 3.98 & Cukup \\
Tanggung Jawab Pendeteksian Kecurangan (X) & 4.25 \\
1 & Menerapkan metode audit & 3.5 & Tinggi \\
2 & Penggunaan alat bantu (decision aids) & Cukup \\
3 & Professional Judgment & 3.5 & Cukup \\
4 & Skeptisisme professional & 4.8 & Rendah \\
5 & Penilaian risiko terjadinya kecurangan dalam perencanaan audit & 4.47 & Baik \\
Total Skor Rata-Rata & 4.21 & Tinggi \\
\hline
\end{tabular}

Sumber: Hasil pengolahan data primer, 2013 
Tabel 3 Pengujian Asosiatif

\begin{tabular}{lccc}
\hline \multicolumn{1}{c}{ Keterangan } & Coefficients & t hitung & Sig. \\
\hline Konstanta & B & 2.986 & .005 \\
$\mathrm{X}$ & 9.560 & 6.343 & $.000^{* *}$ \\
\hline \hline Variabel Terikat: Pencegahan Terjadinya Kegagalan Audit (Y) & & \\
\hline F Hitung & .890 .233 (Sig. 0.000) \\
Korelasi & 0.713 \\
Koefisien Determinasi & $50.8 \%$ \\
\hline
\end{tabular}

Keterangan: ** signifikan pada taraf 5\% (uji satu pihak)

Sumber: Hasil pengolahan data primer, 2013

Bila dilihat berdasarkan indikator, terlihat bahwa rata-rata skor tanggapan responden mengenai melaporkan temuan pemeriksaan yang material dan melakukan pendeteksian kesalahan material termasuk sering. Namun memberikan opini atas laporan keuangan yang sesuai kondisi keuangan yang sebenarnya selalu dilakukan dan kemampuan dalam mengenali kecurangan yang material sudah termasuk baik.

Pengujian hipotesis dilakukan dengan menggunakan regresi sederhana, selain itu juga dapat diketahui berapa besarnya peran tanggung jawab pendeteksian kecurangan terhadap pencegahan terjadinya kegagalan audit, lebih jelasnya dapat dilihat pada Tabel 3 .

\section{PEMBAHASAN}

Tanggung jawab pendeteksian kecurangan yang dilakukan oleh auditor selalu menerapkan metode audit untuk mendeteksi kekeliruan atau kesalahan dalam laporan keuangan perusahaan. Ketika melakukan penugasan audit, auditor juga selalu menggunakan metode audit untuk mendeteksi kekeliruan atau kesalahan dalam laporan keuangan perusahaan. Selain itu seorang auditor selalu menggunakan professional judgment dalam mendeteksi kecurangan dan sebagian besar auditor tidak pernah puas/percaya dengan jawaban yang diberikan oleh pihak manajemen, ketika menanyakan kepada pihak manajemen mengenai pengumpulan dan penilaian bukti audit.
Auditor dalam memberikan opini terhadap laporan keuangan untuk mencegah terjadinya kegagalan audit selalu menyampaikan temuan audit yang material kepada pihak manajemen dan menyampaikan temuan audit yang berkaitan dengan pemalsuan bukti transaksi. Guna memberikan opini yang tepat, seorang auditor haruslah berani untuk tidak memberikan opini wajar tanpa pengecualian (WTP), jika pada kenyataannya penyusunan laporan keuangan perusahaan tidak sesuai dengan standar yang berlaku. Selain itu auditor juga harus dapat menemukan kesalahan pencatatan dalam laporan keuangan yang berkaitan dengan penjumlahan, pengurangan, perkalian, dan pembagian termasuk mengungkapkan temuan yang berhubungan dengan kecurangan.

Berdasarkan hasil pengujian yang telah dilakukan memberikan bukti empiris bahwa semakin tinggi tanggung jawab pendeteksian kecurangan, maka tingkat pencegahan kegagalan audit semakin baik pada Kantor Akuntan Publik yang ada di wilayah DKI Jakarta. Secara langsung tanggung jawab pendeteksian kecurangan memberikan pengaruh sebesar 50,8\% terhadap pencegahan terjadinya kegagalan audit.

Hal tersebut juga didukung oleh hasil penelitian milik Prasetyo (2010) di mana hasil pengujian mengenai variabel "Tanggung Jawab Pendeteksian Kecurangan" memiliki pengaruh yang cukup besar terhadap "Pencegahan kegagalan Audit". Walaupun penelitiannya dilaksanakan di tempat yang berbeda yaitu penelitian sekarang di KAP sedangkan penelitian 
terdahulu di BPK (Audit Ekternal Pemerintah) namun memiliki hasil yang sama, yaitu sama-sama memiliki pengahun yang besar antara "Tanggung Jawab Pendeteksian Kecurangan dan Pencegahan kegagalan Audit.

Besarnya pengaruh tersebut menunjukkan bahwa seorang auditor yang bertanggung jawab terhadap pendeteksian kecurangan akan mampu mencegah kegagalan audit karena mampu menerapkan metode audit yang baik, menjunjung tinggi professional judgement yang objektif, memiliki sifat skeptisisme yang profesional, dan mampu menyampaikan hasil penilaian risiko yang berkaitan dengan kecurangan secara netral walaupun adanya tekanan dari pihakpihak yang berkepentingan.

\section{KESIMPULAN}

Hasil pengujian memberikan bukti empiris bahwa semakin tinggi tanggung jawab pendeteksian kecurangan, maka tingkat pencegahan kegagalan audit semakin baik di wilayah DKI Jakarta.

Terkait keterbatasan peneliti, disarankan kepada peneliti lainnya untuk melakukan penelitian yang menggunakan kuesioner dengan pertanyaan atas suatu kondisi pada tahun tertentu, dan ketika membuat pertanyaan dari kuesioner diharapkan peneliti untuk menyertakan pertanyaan positif dan pertanyaan negatif pada setiap indikator pertanyaan. Disarankan kepada peneliti lainnya untuk meneliti unit kerja lainnya selain di KAP atau memperluas sampel penelitian. Untuk penelitian selanjutnya hendaknya dapat mempertimbangkan faktor-faktor lain yang secara teoritis mempengaruhi pencegahan kegagalan audit, seperti misalnya pembatasan lingkup audit dan skeptisisme profesional.

\section{DAFTAR PUSTAKA}

American Institute of Certified Public Accountants (AICPA). 2002. Statement on Auditing Standards (SAS) No. 99: Consideration of Fraud in Financial Statement Audit. New York.

Agoes, Sukrisno. 2009. Auditing (Pemeriksaan Akuntan), Oleh Kantor Akuntan Publik Jilid II. Jakarta: Universitas Indonesia.

Arens, Alvin A., Randal J. Elder \& Mark S. Beasley. 2012. Auditing and Assurance Services (14 ${ }^{\text {th }}$ edition), New Jersey: Pearson Prentice Hall.
Ballou, Brian., Christine E. Earley \& Jay S. Rich. 2004. The Impact of Strategic Positioning Evaluation on Auditor Judgments about Business Process Performance. AUDITING: A Journal of Practice \& Theory, 23(2): 71-88.

Bazerman, Max H., Kimberly P. Morgan \& George F. Loewenstein. 1997. Opinion: The Impossibility of Auditor Independence. Sloan Management Review, 38(4): 89-94.

Bell, Timothy B., Mark E. Peecher \& Ira Solomon. 2005. The 21st Century Public Company Audit, Conceptual Elements of KPMG's Global Audit Methodology. Switzerland: KPMG International.

Choo, F. \& K. T. Trotman. 1991. The Relationship Between Knowledge Structure and Judgments for Experienced and Inexperienced Auditors. The Accounting Review, 66: 464-485.

Christiawan, Yulius Jogi. 2005. Aktivitas Pengendalian Mutu Jasa Audit Laporan Keuangan Historis. Jurnal Akuntansi \& Keuangan, 7(1): 61- 88.

Filipović, Davor \& Ivica Filipović. 2008. External Auditing and Audit Committee As Mechanisms In Corporate Governance. 4th International Conference An Enterprise Odyssey: Tourism - Governance and Entrepreneurship, Cavtat, Croatia, 11-15 July 2008.

Hackenbrack, Karl. 1992. Implications of Seemingly Irrelevant Evidence in Audit Judgment. Journal of Accounting Research, 30(1): 126-136.

Herusetya, Antonius. 2007. Kewajiban Hukum Bagi Akuntan Publik: Risiko Profesional yang semakin Meningkat. Integrity - Jurnal Akuntansi dan Keuangan, 1(1): 51-62.

Koroy, Tri Ramaraya. 2008. Pendeteksian Kecurangan (Fraud) Laporan Keuangan oleh Auditor Eksternal. Jurnal Akuntansi dan Keuangan, 10(1): 22-33.

Prasetyo, Denny. 2010. Pengaruh Independensi, Kompetensi Dan Tanggung Jawab Pendeteksian Kecurangan Terhadap Pencegahan Kegagalan Audit (Audit Failure). Bandung: Universitas Padjajaran.

Salehi, Mahdi \& Zhila Azary. 2009. Fraud Detection and Audit Expectation Gap: Empirical Evidence from Iranian Bankers International Journal of Business and Management, 3(10): 65-77.

Sekaran, Uma. 2011. Research Methods for Business, Buku 1 (edisi ke-4), Jakarta: Salemba Empat. 
Sekaran, Uma. 2011. Research Methods for Business, Buku 2 (edisi ke-4), Jakarta: Salemba Empat.

Setiawan, Ivan Aries \& Imam Ghozali. 2006. Akuntansi Keperilakuan: Konsep dan Kajian Empiris Perilaku Akuntan. Semarang: Universitas Diponegoro.

Sunarsip. 2002. Menarik Pelajaran dari Skandal Korporasi di AS. Kompas 15 Juli 2002.
Tackett, James, Fran M. Wolf \& Gregory A. Claypool. 2006. A Fraud Specialists on Independent Audits. Journal of Business and Economics Research, 4(7): 63-67.

Tjun, Lauw Tjun, Elyzabet Marpaung \& Santy Setiawan. 2012. Pengaruh Kompetensi dan Independensi Auditor Terhadap Kualitas Audit. Bandung: Universitas Kristen Maranatha. 